\title{
Diet or diet plus physical activity in patients with early type 2 diabetes
}

Citation for published version (APA):

Hesselink, M. K. C., \& Schrauwen, P. (2011). Diet or diet plus physical activity in patients with early type 2 diabetes. Lancet, 378(9809), 2066-7; author reply 2067-8. https://doi.org/10.1016/S0140-6736(11)618928

Document status and date:

Published: 01/01/2011

DOI:

10.1016/S0140-6736(11)61892-8

Document Version:

Publisher's PDF, also known as Version of record

Document license:

Taverne

Please check the document version of this publication:

- A submitted manuscript is the version of the article upon submission and before peer-review. There can be important differences between the submitted version and the official published version of record.

People interested in the research are advised to contact the author for the final version of the publication, or visit the DOI to the publisher's website.

- The final author version and the galley proof are versions of the publication after peer review.

- The final published version features the final layout of the paper including the volume, issue and page numbers.

Link to publication

\footnotetext{
General rights rights.

- You may freely distribute the URL identifying the publication in the public portal. please follow below link for the End User Agreement:

www.umlib.nl/taverne-license

Take down policy

If you believe that this document breaches copyright please contact us at:

repository@maastrichtuniversity.nl

providing details and we will investigate your claim.
}

Copyright and moral rights for the publications made accessible in the public portal are retained by the authors and/or other copyright owners and it is a condition of accessing publications that users recognise and abide by the legal requirements associated with these

- Users may download and print one copy of any publication from the public portal for the purpose of private study or research.

- You may not further distribute the material or use it for any profit-making activity or commercial gain

If the publication is distributed under the terms of Article $25 \mathrm{fa}$ of the Dutch Copyright Act, indicated by the "Taverne" license above, 
England." This means good-quality research that is carefully designed and thoughtfully constructed-something we have yet to see in this area.

We declare that we have no conflicts of interest.

*Allyson Pollock, Azeem Majeed,

Alison Macfarlane, lan Greener, Graham Kirkwood, Howard Mellett,

Sylvia Godden, Sean Boyle, Carol Morelli, Petra Brhlikova a.pollock@qmul.ac.uk

Centre for Primary Care and Public Health, Queen Mary, University of London, London E1 4NS, UK (AP, SG); School of Public Health, Imperial College London, London, UK (AM); School of Health Sciences, City University London, London, UK (AMac); North East Doctoral Training Centre, Durham University, Durham, UK (IG); School of Social and Political Science, University of Edinburgh, Edinburgh, UK (GK, PB); Cardiff Business School, Cardiff University, Cardiff, UK (HM); LSE Health and Social Care, London School of Economics and Political Science, London, UK (SB); and Economic Studies, University of Dundee, Dundee, UK (CM)

1 Bloom N, Cooper Z, Gaynor M, et al. In defence of our research on competition in England's National Health Service. Lancet 2011; published online Nov 8. DOI:10.1016/S01406736(11)61708-X

2 Propper C, Burgess S, Gossage D. Competition and quality: evidence from the NHS internal market 1991-1996. Econ J 2008; 118: 138-70.

3 Pollock A, Macfarlane A, Kirkwood G, et al. No evidence that patient choice in the NHS saves lives. Lancet 2011; published online Oct 10. DOI:10.1016/S0140-6736(11)61553-5.

4 West RM, Cattle BA, Bouyssie M, et al. Impact of hospital proportion and volume on primary percutaneous coronary intervention performance in England and Wales. Eur Heart J 2011; 32: 706-11.

5 Imbens G, Wooldridge J. Recent developments in the econometrics of program evaluation. J Econ Lit 2009; 47: 5-86.

6 Angrist JD, Pischke J-S. The credibility revolution in empirical economics: how better research design is taking the con out of econometrics. J Econ Persp 2010; 24: 3-30.

7 Bevan G, Skellern M. Does competition between hospitals improve clinical quality? A review of evidence from two eras of competition in the English NHS. BMJ 2011; 343: d6470.

\section{Diet or diet plus physical activity in patients with early type 2 diabetes}

R C Andrews and colleagues (July 9, p129) ${ }^{1}$ state as their final interpretation that "The addition of an activity intervention conferred no additional benefits." However, this conclusion is misleading, since the achieved increases in physical activity in the diet plus activity group were insufficient to support it.

In fact, although only one group was instructed to do physical activity, no clinically relevant difference was noted in moderate-tovigorous physical activity versus the "non-sedentary" control and diet intervention groups (31 $\mathrm{min} v \mathrm{~s}$ $26 \mathrm{~min}$ and $27 \mathrm{~min}$, respectively, by accelerometry). The within-group increase from baseline in the diet plus physical activity group was also small (from $23 \mathrm{~min}$ to $31 \mathrm{~min}$ ). We question how such a slight difference in physical activity level could have produced significant effects.

Moreover, no difference between groups was found in sedentary time, minimisation of which could be as important as physical activity for improving cardiovascular risk factors. ${ }^{2}$ In our opinion, the lack of additional benefits in the diet and physical activity group is due to the insufficient increase in volume and intensity of physical activity. Previous randomised trials ${ }^{3-5}$ have clearly shown the beneficial effects of physical activity or exercise, independent of disease duration, contrary to Andrews and colleagues' interpretation in their Research in Context panel

We declare that we have no conflicts of interest.

*Stefano Balducci, Silvano Zanuso, Giuseppe Pugliese, Timothy Church, Ronald J Sigal

\section{sbalducci@esinet.it}

Metabolic Fitness Association, 00015 Monterotondo, Rome, Italy (SB); School of Science, University of Greenwich, London, UK (SZ); Department of Clinical and Molecular Medicine, "La Sapienza" University, Rome, Italy (GP); Pennington Biomedical Research Center, Louisiana State University System, Baton Rouge, LA, USA (TC); and Departments of Medicine, Cardiac Sciences and Community Health Sciences, Faculties of Medicine and Kinesiology, University of Calgary, Calgary, AB, Canada (RJS)

1 Andrews RC, Cooper AR, Montgomery AA, et al. Diet or diet plus physical activity versus usual care in patients with newly diagnosed type 2 diabetes: the Early ACTID randomised controlled trial. Lancet 2011; 378: 129-39.
2 Healy GN, Wijndaele K, Dunstan DW, et al. Objectively measured sedentary time, physical activity, and metabolic risk: the Australian Diabetes, Obesity and Lifestyle Study (AusDiab). Diabetes Care 2008; 31: 369-71.

3 Sigal RJ, Kenny GP, Boulé NG, et al. Effects of aerobic training, resistance training, or both on glycemic control in type 2 diabetes: a randomized trial. Ann Intern Med 2007. 147: 357-69.

4 Balducci S, Zanuso S, Nicolucci A, et al, for the Italian Diabetes Exercise Study (IDES) Investigators. Effect of an intensive exercise intervention strategy on modifiable cardiovascular risk factors in type 2 diabetic subjects. A randomized controlled trial: the Italian Diabetes and Exercise Study (IDES). Arch Intern Med 2010; 170: 1794-803.

5 Church TS, Blair SN, Cocreham S, et al. Effects of aerobic and resistance training on hemoglobin A1c levels in patients with type 2 diabetes: a randomized controlled trial. JAMA 2010; 304: 2253-62.

The Early ACTID trial ${ }^{1}$ shows that a dietary intervention in patients with early diagnosed type 2 diabetes is as effective in reducing glycated haemoglobin $\left(\mathrm{HbA}_{1 \mathrm{c}}\right)$ and blood pressure as is diet plus physical activity. Thus, R C Andrews and colleagues conclude that additional efforts needed to combine dietary advice with advice on physical activity are not justified. Although this conclusion is appropriate in the context of the trial, inclusion of a group doing physical activity only, along with more sophisticated metabolic phenotyping, would have been needed to explore the genuine significance of physical activity treatment for (pre)diabetes.

Muscle insulin resistance is an early detectable hallmark in the pathogenesis of type 2 diabetes that coincides with mitochondrial dysfunction, even in the normoglycaemic prediabetic state. $^{2}$ This finding is partly reflected in reduced metabolic flexibility-the ability to adapt fuel selection to substrate availability (ie, post-prandial vs fasted conditions)-in the insulin-resistant state. In patients with long-standing (>3 years) type 2 diabetes, exercise training without intentional weight loss restored metabolic flexibility. Improved metabolic flexibility was only noted when exercise and diet 
were combined and not when diet was the sole intervention. ${ }^{4}$

$24 \mathrm{~h}$ of continuous glucose monitoring revealed that even a single exercise session reduces cumulative episodes of hyperglycaemia by about $50 \%,{ }^{5}$ and improved metabolic flexibility through training also favours post-prandial glucose handling.

The setting of the Early ACTID trial complicates testing these favourable adaptations. Thus, generalisation of the trial outcome might have the unwarranted side-effect of underrecognition of the power of physical activity in prevention and treatment of early diagnosed type 2 diabetes. Long-term adherence to dietary and physical activity interventions and their combination requires support by well trained health-care workers anyhow. So, why not teach health-care professionals the convincing beneficial effects of exercise?

We declare that we have no conflicts of interest.

\section{*Matthijs KC Hesselink, Patrick Schrauwen \\ Matthijs.hesselink@ maastrichtuniversity.nl}

Department of Human Movement Sciences (MKCH) and Department of Human Biology (PS), School for Nutrition, Toxicology and Metabolism, Maastricht University Medical Centre, PO Box 616, 6200 MD Maastricht, Netherlands

1 Andrews RC, Cooper AR, Montgomery AA, et al. Diet or diet plus physical activity versus usual care in patients with newly diagnosed type 2 diabetes: the Early ACTID randomised controlled trial. Lancet 2011; 378: 129-39.

2 Phielix E, Schrauwen-Hinderling VB, Mensink $\mathrm{M}$, et al. Lower intrinsic ADP stimulated mitochondrial respiration underlies in vivo mitochondrial dysfunction in muscle of male type 2 diabetic patients. Diabetes 2008 ; 57: 2943-49.

3 Meex RC, Schrauwen-Hinderling VB, Moonen-Kornips $\mathrm{E}_{\text {, et al. Restoration of }}$ muscle mitochondrial function and metabolic flexibility in type 2 diabetes by exercise training is paralleled by increased myocellular fat storage and improved insulin sensitivity. Diabetes 2010; 59: 572-79.

4 Amati F, Dube J], Shay C, Goodpaster BH. Separate and combined effects of exercise training and weight loss on exercise efficiency and substrate oxidation. J Appl Physiol 2008; 105: 825-31.

5 Manders RJ, Van Dijk JW, van Loon LJ. Lowintensity exercise reduces the prevalence of hyperglycemia in type 2 diabetes. Med Sci Sports Exerc 2010; 42: 219-25

\section{Authors' reply}

Objective measurement of physical activity in ACTID by use of accelerometers showed that we achieved an increase in activity at 6 and 12 months in the diet and activity group compared with the diet only or usual care groups (see original table 3). This increase in activity was similar to that seen in both the Finnish and American diabetes prevention studies and many other beneficial nonsupervised exercise studies in patients with diabetes. ${ }^{1-3}$ This increase equated to 9 min per day or more than $1 \mathrm{~h}$ per week of additional exercise-an increase of $30 \%$ in the diet and activity group.

Compliance with exercise, as measured by pedometer, was also very good, with an increase of $20 \%$ seen in overall daily steps between baseline and 6 months (6399 [SD 3056] to 7680 [2818]), which was maintained to 12 months and consistent with the $29.9 \%$ increase seen in a metaanalysis of pedometer intervention studies. ${ }^{4}$ Hence lack of performance of the exercise or lack of difference in increased physical activity between the intervention groups is unlikely to explain our findings. The remaining possible interpretations of our results therefore include that participants in the diet and activity group made fewer changes to their diet than did those focusing on diet alone, or that the form of exercise used (similar to that in other unsupervised intervention trials) was not ideal.

Populations involved in supervised exercise programmes, in whom the benefits have most consistently been shown, tend to be more select, younger, have worse diabetes control, have had diabetes for longer, and have substantially more contact time than the population in the ACTID Study. These studies were also not designed to answer the specific question that ACTID set out to answer, namely if you give advice on diet and exercise together, in a real-world, community-based cohort in the first year after diagnosis, is this more effective than giving advice on diet alone? We specifically chose an unsupervised intervention, since with the large numbers of affected patients, resources are unlikely to be available to provide supervised interventions to all patients. Even in an intense supervised exercise programme, aerobic training alone, the form of exercise used in ACTID, does not improve glucose control, ${ }^{5}$ and the most recent review of physical activity in patients with diabetes found that non-supervised exercise is only beneficial if given with dietary advice. $^{5}$

A physical activity alone group, along with more sophisticated metabolic phenotyping, would have enabled us to explore in more detail the effects of this treatment in patients with newly diagnosed diabetes. This was not the aim of ACTID. We aimed to determine whether, in current health-care systems, where greater investments are being made into education programmes to improve patients' diets, there is additional benefit of giving exercise advice over and above comprehensive dietary advice.

Our conclusions were not intended to erode health-care workers' views on physical activity-we too are enthusiasts for increases in physical activity. Rather, they were intended as a "call to arms" for us to invest further in dietary interventions and rigorous pragmatic trials in this area, recognising that what is effective in routine health care is often different from what is effective in more highly controlled mechanistic studies.

RCA has received honoraria from GlaxoSmithKline, Novo Nordisk, Sanofi-Aventis, and Lilly, and travel expenses from Sanofi-Aventis. CMD has received consultancy fees from GlaxoSmithKline and Medtronic Advisery, speaker's fees from Novo Nordisk and Bristol-Myers Squibb, travel expenses from Medtronic, and is named on a patent held by Novartis. The other authors declare that they have no conflicts of interest.

${ }^{*} R C$ Andrews, A R Cooper, A A Montgomery, TJ Peters, D J Sharp, CM Dayan rob.andrews@bristol.ac.uk

School of Clinical Sciences, University of Bristol, Bristol BS1 3NY, UK (RCA, TJP); Centre for Exercise, Nutrition and Health Sciences, School for Policy Studies, University of Bristol, Bristol, UK (ARC);

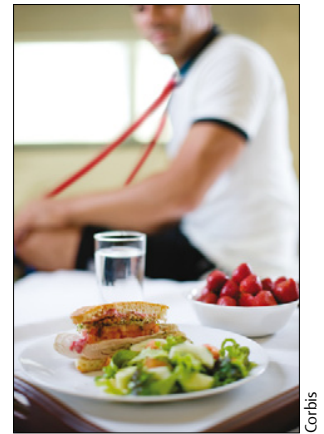

